ROCZNIKI PEDAGOGICZNE

Tom 12(48), numer $3-2020$

DOI: https://doi.org/10.18290/rped20123-3

ARKADIUSZ WĄSIŃSKI

\title{
BIOGRAFIE MAŁŻEŃSKIE I RODZINNE ROZPATRYWANE W PERSPEKTYWIE AUTOKREACJI DO RODZICIELSTWA
}

\author{
1. WPROWADZENIE - RÓŻNE PERSPEKTYWY \\ ODNIESIENIA SIE DO RODZICIELSTWA
}

Rodzicielstwo jest utożsamiane $\mathrm{z}$ aktem zrodzenia $\mathrm{z}$ siebie człowieka, przekazaniem mu życia, daniem początku nowemu ludzkiemu istnieniu. Rodzicielstwu przypisuje się doniosłe znaczenie w ludzkim życiu. Przyjmując perspektywę ciągłości gatunku, można stwierdzić, że jest ono gwarantem życia kolejnych pokoleń. W ujęciu osobniczym jest jednym z najważniejszych aspektów rozwoju człowieka dorosłego, a w wymiarze społecznym źródłem szczególnie silnej i trwałej więzi łączącej ludzi. Z kolei rozpoznawane na płaszczyźnie egzystencjalnej rodzicielstwo jest uczestniczeniem w tajemnicy ludzkiego życia.

W perspektywie pedagogicznej rodzicielstwo konstytuuje wspólnotę rodzinną, jest ono źródłowe dla jej istnienia i jakości funkcjonowania. Odnosi się do różnych aspektów macierzyństwa i ojcostwa; władzy rodzicielskiej jako swoistego zobowiązania wobec dziecka i odpowiedzialnego angażowania się w dbałość o jego dobro; miłości rodzicielskiej, uszlachetniającej w sposób bezwarunkowy, bezinteresowny i trwały sytuację spotkania rodzica z dzieckiem; opieki zapewniającej właściwe zaspokajanie potrzeb rozwojowych dziecka; wychowania jako przestrzeni dialogu rodzica z dzieckiem, rozbudzającego w nim gotowość do aktualizowania własnego potencjału osobowego; odkrywania i rozumienia siebie na drodze osobowej autokreacji.

Dr hab. ARKADIUSZ WĄSIŃSKi, prof. UŁ - Katedra Andragogiki i Gerontologii Społecznej, Wydział Nauk o Wychowaniu, Uniwersytet Łódzki; adres do korespondencji: ul. Narutowicza 68, 90-136 Łódź; e-mail: arkadiusz.wasinski@gmail.com; ORCID: https://orcid.org/0000-00031867-8541. 
Rodzicielstwo wielowymiarowo przenika i współkształtuje przestrzeń życia rodzica i dziecka. W rozważaniach pedagogicznych jest zazwyczaj rozpatrywane z perspektywy dziecka. Wiąże się wówczas z eksponowaniem roli każdego z rodziców w zapewnieniu warunków materialnych, bezpieczeństwa i stabilizacji życiowej dziecka, angażowaniu się w kształtowanie i rozwijanie relacji rodzicielskiej z własnym dzieckiem, budowaniu atmosfery wychowawczej w domu rodzinnym, trosce o dobro dziecka, rozpoznawane praktycznie w każdej sferze jego życia i rozwoju. Bycie rodzicem oznacza w tym kontekście wywiązywanie się z całego spektrum powinności moralnych i zobowiązań społeczno-prawnych wobec dziecka.

Zgoła odmienne aspekty rodzicielstwa ujawniają się wówczas, gdy jest ono rozpatrywane z punktu widzenia rodzica (ojca, matki). Zmiana perspektywy wiąże się z eksponowaniem świadomego, autorefleksyjnego przeżywania rzeczywistości bycia rodzicem. Oznacza więc inne spojrzenie na relację rodzica z dzieckiem, zogniskowane wokół specyfiki doświadczania bycia, a raczej nieustannego stawania się rodzicem na drodze jego osobowej autokreacji (Wąsiński, 2018). Rodzicielstwo jest wówczas utożsamiane z osobowym rozwojem rodzica, inspirowanym i nieustannie wzbudzanym $\mathrm{w}$ przestrzeni obcowania z dzieckiem. Wiąże się z odwróceniem sposobu doświadczania relacji z dzieckiem. Fakt obecności dziecka dynamizuje więc osobową autokreację rodzica. Unaocznia mu zasadnicze znaczenie wzajemności doświadczanej w relacji rodzicielskiej. Rodzic wnosi w życie dziecka nowe wartości, współkreuje jego osobową zmianę, ale też przyjmuje od dziecka dar jego obecności i miłości. A zatem rodzicielstwo widziane z tej perspektywy ma również dla rodzica znaczenie osobotwórcze (Kornas-Biela, 2009, s. 103-105).

\section{DYSKUSJA WOKÓŁ ZŁOŻONEJ NATURY RODZICIELSTWA ROZPATRYWANEGO Z PERSPEKTYWY RODZICA}

Naturę rodzicielstwa rozpatrywanego z perspektywy rodzica daje się w jakimś przybliżeniu zrozumieć, podejmując namysł nad istotą ludzkiej egzystencji. Istotne znaczenie zyskuje w tym kontekście różnica między rozumieniem rodzicielstwa, utożsamianego z przestrzenią aktywności prokreacyjnej człowieka, a szerszym jego rozumieniem, łączonym $\mathrm{z}$ duchowym zrodzeniem z siebie człowieka. Wymownie ujmuje tę kwestię V. Frankl: „Rodzice przekazują dziecku przy jego poczęciu swoje chromosomy, ale ducha tchnąć weń nie potrafią. Chromosomy wyznaczają jedynie i wyłącznie psychofizyczną 
strukturę człowieka, ale nie jego ducha, określają jedynie organizm psychofizyczny, ale nie duchową osobę. Jednym słowem, dzięki odziedziczonym, przekazanym mu przez rodziców chromosomom człowiek zostaje określony tylko w dziedzinie tego, co $m a$, ale nie w dziedzinie tego, czym jest" (Frankl, 1998, s. 243-244).

Złożony charakter kategorii zrodzenia z siebie człowieka sprzyja pełniejszemu rozumieniu zdolności człowieka do przekazania życia, którą w wymiarze biologicznym oznaczają płodność i prokreacja. Świadomość własnej płodności daje poczucie gotowości do przekazania życia i samostanowienia o kierunku własnych dążeń i konkretnych działań w tym zakresie. Płodność jest tym atrybutem rodzicielstwa, który $\mathrm{w}$ akcie prokreacji uzdalnia człowieka do projektowania własnego życia rodzinnego (por. Rowid, 1946, 132-155). W tym sensie płodność i prokreacja są immanentnymi komponentami rodzicielstwa. Ich znaczenie ujawnia się nawet w sytuacji deklarowanego bra$\mathrm{ku}$ zainteresowania bycia rodzicem. Projektowanie własnej drogi życiowej polega bowiem na rozpoznaniu potencjału osobowego i świadomości podmiotowej wolności w jego aktualizowaniu i rozwijaniu. Postanowienie o braku woli realizowania się w rodzicielstwie, niezależnie od tego, czy okaże się trwałe, czy zostanie skorygowane w jakimś momencie życia, jest przejawem samostanowienia w sferze dysponowania własną płodnością (por. Ładyżyński, 2009, s. 259-269; Świątkiewicz, 2016, s. 142-143; Kornas-Biela, 2000, s. 110-115).

Wspomniana różnica wiąże się, z jednej strony, z eksponowaniem biologicznego wymiaru rodzicielstwa jako tego, w którym rozgrywa się rzeczywistość rodzicielstwa, a z drugiej, z eksponowaniem noologicznego wymiaru rodzicielstwa jako tego, w którym rzeczywistość ta zyskuje złożony, wielowymiarowy charakter. Należy nadmienić, że wielowymiarowe rozumienie rodzicielstwa bazuje na założeniu integralności i jedności bio-psycho-duchowej człowieka (integralną koncepcję człowieka podejmowali w swych pracach m.in. Wojtyła, 2000, 2003; Guardini, 1993; Krąpiec, 2005; Bartnik, 2008; Chudy, 2009; Frank1, 1998; Popielski, 1996) oraz jej pedagogicznych konceptualizacji (zob. m.in. Kunowski, 1997; Nowak, 2001; Kostkiewicz, 2013; Folkierska, 2005; Śliwerski, 2011; Olbrycht, 2000; Kornas-Biela, 2009; Kiereś, 2016; Horowski, 2015; Starnawski, 2012; Cyrańska, 2005).

Rozumienie rodzicielstwa jako wielowymiarowej rzeczywistości nakreśla ramy bycia rodzicem, czyli autorefleksyjnym podmiotem, podejmującym rozumiejący wgląd w siebie, rozpoznającym w rodzicielstwie szansę egzystencjalnego stawania się i spełnienia. Wiąże się więc ze spojrzeniem na 
rodzicielstwo jako rzeczywistość świadomie przeżywanego bycia rodzicem, co więcej - jako rzeczywistość sprzyjającą transformatywnemu uczeniu się biograficznemu (por. Jarvis, 2012, s. 127-134). Rzeczywistość ta uzdalnia zatem rodzica do twórczego rozpoznawania siebie jako podmiotu świadomego osobotwórczego znaczenia własnych wyborów, rozstrzygnięć i czynów; podmiotu zaangażowanego $\mathrm{w}$ ciągłe stawanie się $\mathrm{w}$ rodzicielstwie. Sprzyja ona więc rozpatrywaniu rodzicielstwa jako dynamicznego i złożonego procesu osobowej autokreacji rodzica.

Noetyczny kontekst myślenia o rodzicielstwie koncentruje uwagę na rodzicu (matce/ojcu) zwracającego się ku drugiemu człowiekowi (córce/synowi) jako równowartościowemu podmiotowi osobowemu. Perspektywa ta zakłada osobliwy charakter rodzicielstwa jako istotnego egzystencjalnie doświadczenia biograficznego. Kształtuje się ono na podłożu osobistego doświadczania rodzicielstwa i przeżywania samego siebie $\mathrm{w}$ rodzicielstwie. Nikt bowiem nie jest w stanie doświadczyć rodzicielstwa niejako w zastępstwie za rodzica, ani wyręczyć go w realizowaniu się w rodzicielstwie. Podobnie jak nikt nie jest $\mathrm{w}$ stanie wyręczyć rodzica $\mathrm{w}$ doświadczeniu miłości rodzicielskiej rozumianej jako daru kierowanego do dziecka. Za każdym razem jest to indywidualna odpowiedź każdego rodzica na wezwanie miłości w kontekście osobowej relacji z dzieckiem. Istotę tego kluczowego w ludzkim życiu wezwania odsłania sekwencja trzech momentów: powinnościowego, moralnego i egzystencjalnego, które S. Kierkegaard ujmuje następująco: „Ty powinieneś kochać bliźniego” (2008, s. 38-103).

Tym samym punktem wyjścia do rozważań dotyczących natury rodzicielstwa jest w niniejszym artykule zaistnienie prostej w swej strukturze, dwupodmiotowej relacji współtworzonej przez dwoje ludzi, którzy definiują siebie jako rodzic i dziecko. O ile jednak dwupodmiotowy charakter struktury tej relacji jawi się jako nieskomplikowany, o tyle jej analiza odsłania ukonstytuowaną na niej złożoną naturę rodzicielstwa. Można ją rozpatrywać z perspektywy rodzica (ojca/matki), dziecka (córki/syna), wspólnoty małżeńskiej, a także otoczenia społecznego w płaszczyźnie rodzinno-sąsiedzkiej i instytucjonalnej. Przyjęcie perspektywy rodzica odsłania jej specyfikę w różnych obszarach i kontekstach zogniskowanych wokół zobowiązań i powinności wobec dziecka, społeczno-kulturowych uwarunkowań bycia w roli, możliwości osobowego rozwoju na różnych etapach dorosłości, szansy spełnienia egzystencjalnego w sytuacji spotkania z drugim człowiekiem (własnym dzieckiem). 
Podjęte w niniejszym artykule rozważania koncentrują się wokół nieoczywistych przesłanek ujawniających niejednorodny charakter rozumienia rodzicielstwa. Takie podejście analityczne sprzyja uchwyceniu całego spektrum indywidualnych koncepcji rodzicielstwa kształtowanych na podłożu andragogicznych kategorii dorosłości, dojrzałości, doświadczenia i biograficzności (zob. Alheit, 1994; Czerniawska, 1996; Malewski, 1990; Dubas, 2009; 2015; Lalak, 2010). Warto w tym kontekście podkreślić pewną współzależność polegającą na tym, że sposób przeżywania siebie jako osoby dorosłej i kierowania własnym życiem współkształtuje sposób indywidualnego odniesienia się do rodzicielstwa. Współkształtuje więc też sposób przeżywania siebie jako rodzica. Idąc tym tokiem myślenia, ujawnia się napięcie, na którego biegunach można odnaleźć odmienne perspektywy rozumienia bycia rodzicem łączone $\mathrm{z}$ podejściem adaptacyjnym oraz autokreacyjnym. Pierwsze $\mathrm{z}$ wymienionych koresponduje $\mathrm{z}$ socjologicznym paradygmatem dorosłości. Z kolei drugie pozostaje w bliskim związku z paradygmatem auksologicznym, a także biograficznym (Dubas, 2005; 2009; Świtalski, 2015).

Napięcie to odsłania odmienne, a nawet przeciwstawne stanowiska w zasadniczych kwestiach związanych z indywidualnym odniesieniem się osoby dorosłej do siebie jako rodzica, do drugiego człowieka jako własnego dziecka, a także do relacji rodzicielskiej jako przestrzeni towarzyszenia drugiemu człowiekowi. Stanowiska te rozpatrywane w kontekście przywołanych paradygmatów dorosłości grupują się wokół dwóch zasadniczych kwestii, które zyskują pierwszoplanowe znaczenie (por. Glanc, 2011; Urbański, 1986), tj.:

a) koncentracji na zadaniach przypisywanych zgodnie z obowiązującym $\mathrm{w}$ danym systemie społecznym wzorcem do roli rodzica $\mathrm{z}$ silnym wyakcentowaniem wartości odpowiedzialności i samodzielności bycia rodzicem;

b) koncentracji na osobotwórczym charakterze bycia i stawania się rodzicem rozpoznawanym $w$ sytuacji spotkania $z$ drugim człowiekiem uznawanym za własne dziecko.

Koncentracja na zadaniach symbolizuje identyfikację człowieka dorosłego ze społeczno-kulturowymi wzorami pełnienia roli rodzica. Rodzicielstwo rozpoznawane jest, co prawda, jako zadanie rozwojowe wywiedzione $\mathrm{z}$ naturalnego biegu życia człowieka dorosłego, lecz nie jest powiązane z pracą nad sobą ukierunkowaną na osiąganie dojrzałości rozpoznawanej w byciu mądrym i dobrym rodzicem. W tym kontekście rodzicielstwo jest czymś, co jest dane człowiekowi dorosłemu, jeśli zaistnieją w jego życiu czynniki obiektywne, jak narodzenie się lub adopcja dziecka, uznanie dziecka, wejście $\mathrm{w}$ rolę rodzica, założenie rodziny lub utrzymywanie $\mathrm{z}$ dzieckiem 
ustabilizowanych kontaktów. Uzyskanie statusu rodzica jest wówczas traktowane jako trwałe i niezmienne, stanowi niezacieralny przymiot osoby dorosłej. W sensie biograficznym oddziela on wcześniejsze etapy życia od etapu, w którym podjęta została rola rodzica. Takie rozumienie rodzicielstwa zakłada asymetryczność oczekiwanych zmian rozwojowych, które w relacji rodzic-dziecko są wyłącznie po stronie dziecka. Uznaje się więc, że ktoś, kto podjął rolę rodzica, sam jest już ukształtowany jako osoba dorosła i nie wymaga wysiłku pracy nad sobą.

Przeciwstawne ujęcie rodzicielstwa zachodzi w sytuacji koncentracji na osobotwórczym charakterze bycia i stawania się rodzicem. Sens bycia rodzicem ujawnia się w dążeniu człowieka dorosłego do stawania się w rodzicielstwie, które zachodzi na podłożu szczególnego i niepowtarzalnego charakteru towarzyszenia dziecku na wszystkich etapach jego rozwoju i w każdej sytuacji życiowej (por. Kornas-Biela, 2001; Ładyżyński, 2014). Przyjęcie takiej perspektywy rodzicielstwa prowadzi do wniosku, że nie jest ono utożsamiane ze stanem, lecz procesem urzeczywistniania dynamicznej wartości towarzyszenia dziecku. Nakreśla ona rozumienie rodzicielstwa jako rzeczywistości in statu nascendi, a więc rzeczywistości, która nie daje się zamknąć w określonym kontekście społeczno-kulturowym i podlega ciągłemu procesowi kształtowania. Bycie rodzicem jest w tym kontekście istotnym egzystencjalnie wyzwaniem, którego podjęcie wymaga od rodzica nieustannej pracy nad sobą. Co więcej, rozbudza jego osobowy potencjał uzdalniający go do rozwijania coraz bardziej dojrzałych form towarzyszenia własnemu dziecku. W tym sensie rodzicielstwo nie jest dane, lecz zadane człowiekowi dorosłemu, ponieważ stanowi dla niego wyzwanie osiągania osobowej dojrzałości (Kornas-Biela, 2009; Opozda, 2012). Niesie nadzieję na to, co może się w jego życiu wydarzyć na wiele sposobów i co może być budujące, ale też wiąże się z ryzykiem niepowodzenia, utratą nadziei na osiągnięcie spełnienia. Źródłem wspomnianej niepewności jest bowiem ryzyko nieuniesienia „ciężaru” powinności osobowego rozwoju jako warunku dla dojrzałego i mądrego towarzyszenia własnemu dziecku. Źródłem nadziei jest z kolei świadomość samostanowienia, które uzdalnia człowieka dorosłego do kreowania własnej rzeczywistości rodzicielstwa poprzez ciąg nieoczywistych wyborów, rozstrzygnięć i czynów związanych z koniecznością samookreślania się wobec perspektywy bycia rodzicem i wielokrotnego potwierdzania woli bycia rodzicem (Wąsiński, 2018). Rodzicielstwo rozumiane jako rzeczywistość podlegająca ciągłemu procesowi powstawania jest $\mathrm{w}$ istocie emanacją osobowej autokreacji człowieka dorosłego, przeżywaniem siebie jako rodzica 
i projektowaniem indywidualnej drogi realizowania się $\mathrm{w}$ byciu rodzicem. W tym znaczeniu stanowi rzeczywistość zmienną, nieokreśloną, nieprzewidywalną, ale i fascynującą, wyjątkową oraz niepowtarzalną w ludzkim życiu. $\mathrm{Z}$ tych też powodów ta właśnie perspektywa rozumienia rodzicielstwa będzie brana pod uwagę w dalszym toku rozważań w niniejszym artykule.

\section{BIOGRAFICZNY WYMIAR AUTOKREACJI DO RODZICIELSTWA}

Przyjęcie rozstrzygnięć dotyczących osobotwórczego charakteru rodzicielstwa rozpatrywanego na podłożu dynamizmu autokreacji człowieka dorosłego odsłania nowe obszary jego dążenia do bycia i stawania się rodzicem. $\mathrm{Z}$ jednej strony ujawnia się wielowymiarowa struktura autokreacji jako całożyciowego osiągania dojrzałości osobowej, na którą w myśl mojej autorskiej koncepcji składają się następujące wymiary: autoedukacyjny, autorefleksywny, afirmatywny, autoteleologiczny, etyczny i właśnie biograficzny (Wąsiński, 2018). Z drugiej zaś, ujawnia się charakter powiązań między aktywnością biograficzną podejmowaną $\mathrm{w}$ przestrzeni wspólnoty małżeńskiej i rodzinnej z autokreacją do rodzicielstwa. Ze względu na ograniczone ramy tekstu dalsza dyskusja zostanie skoncentrowana na drugim $z$ wymienionych aspektów.

Stwierdzenie, że człowiek jest istotą biograficzną, zakłada zasadnicze znaczenie biografii w całożyciowym planie jego egzystencji (Dubas, 2017). Biografia nie jest efektem mechanicznego zapamiętywania tego, co się wydarzyło, statycznym wyliczeniem uporządkowanych chronologicznie zdarzeń, lecz efektem toczącego się wewnętrznego dialogu, w którym zespoleniu ulega przeszłość z teraźniejszością i przyszłością (por. Rosenthal, 2000). Wspomnienia nie są rekapitulacją przeszłości, lecz przeszłością w teraźniejszości - są przeszłością interpretowaną i konstruowaną przez podmiot (Rytkönen, 2004). Wspomniane dialogowanie z samym sobą jest więc katalizatorem osobliwej opowieści o własnym życiu, która - niezależnie od jej atrakcyjności w odbiorze społecznym - w mniej lub bardziej refleksyjny i rozbudowany sposób pogłębia świadomość siebie w perspektywie własnej drogi życiowej. Opowieść ta staje się - ujmując to metaforycznie - lustrem, w którym człowiek, przegląajając się, przypomina sobie i utrwala różne obrazy siebie z przeszłości i zderza je z aktualnym obrazem siebie. Dzięki czemu dawne jego ja utrwalone w pamięci biograficznej składa się na jego aktualne ja realne, osadzone w konkretnym „tu i teraz”. Tym samym człowiek jako 
podmiot własnej biografii, zaangażowany w permanentne jej rekonstruowanie i reinterpretowanie, wciąż odkrywa siebie na nowo. Rezultatem tej swoistej pracy biograficznej jest poczucie ciągłości własnej tożsamości w każdym momencie życia (Strauss, 1993; Kaźmierska, 2012; Bennett, 2015). Człowiek, stając się wciąż kimś innym, „interpretuje swoją własną przeszłość, ustala swą tożsamość, która niemal za chwilę stanie się inną, gdy pamięć i niepamięć utworzą inną konfigurację" (Kaniowska, 2003, s. 61). Nie sposób więc pomyśleć o egzystencji człowieka usytuowanej poza biografią. Każdy bowiem człowiek zawsze ma jakąś historię własnego życia, którą może opowiedzieć i której jest bohaterem (Skarga, 1995). W tym sensie jest on twórcą i zarazem nosicielem własnej biografii, poprzez którą wyraża siebie i zwraca się ku drugiemu człowiekowi i światu.

Centralnym aspektem biografii jest autorefleksyjne odniesienie się człowieka dorosłego do własnego życia. Refleksja biograficzna pozwala bowiem na rozumiejący wgląd w samego siebie, poznawanie i rozumienie wewnętrznego świata podmiotu, jego własnych „przeżyć, dążeń, sposobów organizacji doświadczenia i działania w świecie" (Lalak, 2010, s. 396). Biograficzny opis życia i refleksja nad nim polega na eksponowaniu tych wydarzeń, doznań i przeżyć, które spostrzegane są jako subiektywnie ważne. Nadanie im konkretnych znaczeń włącza je do struktury doświadczeń biograficznych. Człowiek dorosły podejmujący namysł nad własnym życiem staje się podmiotem przeżywającym siebie w perspektywie własnych pragnień (chceń), wyborów i czynów, a także różnych zdarzeń i zachowań innych ludzi w otaczającej go rzeczywistości społecznej.

Przyjęcie takiego toku myślenia prowadzi do wniosku, że biografia łączy się z:

a) życiem opowiadanym i przekazywanym innym ludziom jako retrospektywnej, domkniętej interpretatywnie narracji opisującej i wyjaśniającej jego przebieg, specyfikę własnych doznań i przemyśleń,

b) życiem rekonstruowanym w odpowiedzi na konieczność nieustannego konfrontowania się podmiotu z dynamicznie zmieniającym się światem,

c) życiem kreowanym w myśl indywidualnej koncepcji siebie, czy też inaczej to ujmując, projektu bycia i stawania się na drodze rozwoju osobowego.

Biografia rozpatrywana jako życie kreowane wiąże się z orientacją podmiotu ku przyszłości utożsamianej z atrakcyjnym życiowo wyzwaniem, nie zaś autodestrukcyjną walką z przeciwnościami losu (Wąsiński, Górniok-Naglik, 2018; Bron, 2009). Podejście to odsłania jej prospektywny charakter. Bazuje bowiem na zdolności człowieka do autorefleksyjnego odniesienia 
się do własnego życia, umożliwiającego kreatywne jego projektowanie i przebudowywanie (Skibińska, 2006). Autokreacyjne znaczenie biografii ujawnia się zatem $\mathrm{w}$ aspekcie sprawczości człowieka dorosłego przejawiającej się w zdolności do przekraczania podmiotowych i ponadpodmiotowych (społecznych) ograniczeń hamujących proces indywidualnego rozwoju. A w tym kontekście - w zdolności do przeżywania siebie jako podmiotu faktycznie kierującego własnym życiem (Alheit, 1995).

Aktywność biograficzna człowieka dorosłego zasadza się zatem na poczuciu sprawstwa związanego z kreowaniem własnej koncepcji rodzicielstwa i możliwością nieustannego jej rekonstruowania w trakcie zdobywania nowych doświadczeń w procesie bycia i stawania się rodzicem. Tak więc prospektywne nastawienie $\mathrm{w}$ autokreacji do rodzicielstwa zakorzenione jest w doświadczeniach biograficznych będących emanacją przeszłości utrwalonej w pamięci biograficznej rodzica. W sytuacji, gdy jest on osobą refleksyjną, angażującą się w pracę biograficzną, wspomniane zakorzenienie w przeszłości nie jest balastem, lecz jego kapitałem biograficznym. Nie zamyka go w bezkrytycznym powielaniu „cudzych” wzorów i modeli rodzicielstwa przekazywanych $\mathrm{w}$ procesie transmisji międzypokoleniowej $\mathrm{w}$ przestrzeni domu rodzinnego, lecz inspiruje go do pogłębionego namysłu nad istotą rodzicielstwa we własnym życiu. Autokreacyjne znaczenie namysłu biograficznego człowieka dorosłego bazuje na uznaniu wartości rodzicielstwa jako procesu osiągania osobowej dojrzałości. Z każdym aktem autokreacji będącym przejawem intencjonalnego kierowania własnym życiem jego egzystencja nabiera „biograficznej niepowtarzalności i stanowi najpełniejszy wyraz człowieczeństwa" (Czerniawska, 1999, s. 80; por. Bakiera, 2013). Trafne wydaje się zatem stwierdzenie: „przyszłość najbardziej odsłania czasowość egzystencji, wyznacza bycie ku czemuś, ale też i nadaje sens przeszłości, która z kolei będąc przyszłości źródłem sprawia, że egzystencja Ja jest nieustannym oczekiwaniem tego, co dopiero będzie; oczekiwaniem 'ukształtowanym' niejako przez to, co już się zdarzyło" (Kaniowska, 2003, s. 61).

\section{FENOMEN AUTOKREACJI DO RODZICIELSTWA W ŚWIETLE WSPÓŁKREACJI ORAZ BIOGRAFII MAŁŻEŃSKIEJ I RODZINNEJ}

Dotychczasowe rozważania eksponowały indywidualny charakter biografii rozpatrywanej w integralnym związku z autokreacją. Warto jednak zauważyć, 
że ze względu na fakt trwania człowieka dorosłego (małżonka lub/i rodzica) w sieci relacji i zależności małżeńskich oraz rodzinnych jego aktywność biograficzna integralnie wkomponowana w proces osobowej autokreacji nie przebiega w próżni społecznej. W praktyce życia codziennego procesy te choć zachowują swoją odrębność i swoistość - współwystępują w przestrzeni wspólnoty rodzinnej z biografią małżeńską i rodzinną oraz współkreacją.

Punktem wyjścia do uchwycenia specyfiki relacji autokreacji i współkreacji jest dostrzeżenie, że istotą autokreacji jest jej zorientowanie na działanie $w$ sobie i z siebie (Ostasz, 1995). Prowadzi to do wniosku, że autokreacja nie jest rozumiana jako proces wyabstrahowany od rzeczywistości innych ludzi, lecz wręcz odwrotnie - jest procesem otwierającym podmiot na drugiego człowieka. Autokreacja nie wzmacnia w świadomości podmiotu nastawienia egocentrycznego do otaczającego świata społecznego i dążenia do bycia dla siebie, ale rozbudza w nim i wzmacnia ciekawość drugiego człowieka powiązaną z pragnieniem obcowania $\mathrm{z}$ nim i dla niego. W tym wyraża się sens autokreacji do rodzicielstwa. Im bardziej rodzic jest zaangażowany w rozbudzanie i dynamizowanie działań autokreacyjnych, tym bardziej zbliża się on mentalnie i duchowo do dziecka, dostrzegając $\mathrm{w}$ nim równowartościową osobę i podmiot życia rodzinnego. Osobotwórczy sens autokreacji rodzica wyraża się w osiąganiu kolejnych stopni dojrzałego towarzyszenia dziecku na każdym etapie jego rozwoju i sytuacji życiowej (Wąsiński, 2018).

Tak rozumiana autokreacja uzdalnia rodzica do kształtowania relacji z dzieckiem w sytuacji spotkania nienaiwnego, to jest takiego, które sprzyja integralnemu rozwojowi osobowemu zarówno rodzica, jak i dziecka. Każde nienaiwne spotkanie rodzica $\mathrm{z}$ dzieckiem, odczytywane jako spotkanie istotne egzystencjalnie, jest otwarciem się na współkreację w przestrzeni wspólnoty rodzinnej. Oznacza ono świadome godzenie się rodzica na to, że inni domownicy mogą coś zainicjować i przyczynić się do jakiejś zmiany w jego życiu, mogą wpłynąć na jego sposób myślenia i przeżywania. Spotkanie nienaiwne uruchamia więc współkreację, która wówczas może, z jednej strony, osłabiać lub wzmacniać dynamikę procesu osobowej autokreacji, a z drugiej - wytyczać jego kierunek (Ostasz, 1995). Rozpatrywanie autokreacji w świetle współkreacji wiąże się z założeniem, że sens życia odsłania się dopiero $\mathrm{w}$ sytuacji bycia z innymi i dla innych. Wówczas ,ja [podmiotu] współtworzy ty, a ty współkreuje $j a$ ", ujawniając hermeneutyczny sposób poznawania drugiego człowieka (Górniok-Naglik, 2014, s. 160). Polega on na wychodzeniu rodzica od wewnątrz siebie, poza własne $j a$ do ty dziecka i jednoczesnym powracaniu od niego do wewnątrz siebie. 
Z kolei fenomen biografii zbiorowej wyraża się w poczuciu łączności i bliskości członków rodziny, którzy „dzielą horyzont doświadczeń życia rodzinnego" utrwalonych w pamięci biograficznej wielu pokoleń (Kasztelan, 2012, s. 187). Różnice między zbiorowym a indywidualnym wymiarem pamięci biograficznej ujawniają się w tym, że pamięć zbiorowa:

a) ukazuje zdarzenia z przeszłości z perspektywy przeżyć i losów konkretnych ludzi, z tego też powodu nie służy pełnemu wyjaśnieniu przeszłości, lecz jest swojego rodzaju polemiczną konstrukcją wobec pamięci zbiorowych innych rodzin;

b) ma wyrazistą strukturę narracyjną wyrażającą się w przekazach międzypokoleniowych przybierających różne formy, np. historii rodzinnych, relacji świadków, opowieści;

c) wiąże się z jednoznacznymi interpretacjami obrazów przeszłości, „które utrwalają, uogólniają i ujednolicają wspomnienia" rodzinne (tamże).

Zbiorowy charakter biografii identyfikowany z biografią małżeńską i rodzinną eksponuje znaczenie autorefleksyjnego odniesienia się człowieka dorosłego do własnego życia rozpoznawanego w perspektywie znaczących innych, wywodzących się z najbliższego otoczenia rodzinnego. Jednocześnie uwyraźnia niejednorodną naturę myślenia „biograficznego” we wspólnocie małżeńskiej i rodzinnej ujawniającego się w wewnętrznym napięciu między przenikającymi się i interferującymi biografiami indywidualnymi każdego z domowników a biografią zbiorową, kształtowaną przez nich jako podmiot wieloosobowy. Biografia zbiorowa jest czymś w rodzaju zwornika zespalającego wspólnotę małżeńską i rodzinną ze światem, którego jest ona elementem integralnym, a zarazem odrębną i autonomiczną przestrzenią życia społecznego.

Biografie zbiorowe są utożsamiane $\mathrm{z}$ dynamicznie współtworzonymi i podlegającymi ciągłym zmianom przestrzeniami symbolicznej jedności w sposobie emocjonalnego, intelektualnego i duchowego przeżywania wydarzeń, które mają w świadomości członków wspomnianych wspólnot istotne znaczenie. Uczestnictwo w zbiorowym rekonstruowaniu struktur doświadczeń biograficznych zespala ich i integruje. Dokonuje się bowiem na drodze wieloosobowego dialogu małżeńskiego i rodzinnego przyczyniającego się do utrwalania i rozwijania specyficznego, wspólnotowego języka, modelu komunikacji, obrazu przeszłości (małżeńskiej i rodzinnej), mentalności, moralności i duchowości. Dialog ten odgrywa kluczową rolę w podtrzymywaniu poczucia ciągłości wspólnotowej tożsamości (Ostrouch-Kamińska, 2017). Współtworzenie i utrwalanie biografii zbiorowych ma więc znaczenie dla 
współtworzących je osób z punktu widzenia ich dążenia do samopoznawania się i samorozumienia, a także konieczności samookreślania się w sytuacjach trudnych, zwłaszcza tych, które inicjują przełomy biograficzne w ich życiu (por. Rosenthal, 2002; Kuryś-Szyncel, 2010).

Należy w tym kontekście zauważyć, że biografie wspólnotowe (małżeńskie i rodzinne) są ukonstytuowane na wspólnotowym doświadczeniu trudu przekraczania siebie przez ich członków. Doświadczenie to wiąże się z wolą przechodzenia od myślenia i postępowania w kategoriach ja podmiotu przeżywającego, zmagającego się, pragnącego, dążącego do czegoś, kierującego się nadzieją ku czemuś do myślenia i postępowania w kategoriach my małżeństwa i rodziny. Owo my jest wówczas nową jakością w życiu domowników. Symbolizuje ono gotowość do dojrzałego uczestniczenia w życiu wspólnoty polegającego na dostrzeganiu dobra własnego i innych jej członków w perspektywie dobra ich wspólnoty (małżeńskiej, rodzinnej) i podejmowaniu działań zorientowanych na jego realizację. Myślenie i działanie w kategorii my wspólnoty symbolizuje jedność z innymi, ze względu na wartość doświadczania obecności bliskich osób i możliwości uczestniczenia w ich życiu.

\section{ZNACZENIE BIOGRAFII MAŁŻEŃSKIEJ I RODZINNEJ W PERSPEKTYWIE AUTOKREACJI DO RODZICIELSTWA ADOPCYJNEGO}

Biografia małżeńska odgrywa istotne znaczenie na etapie preparentalnym rodzicielstwa adopcyjnego rozpoznawanego zarazem w płaszczyźnie indywidualnej odnoszonej do obojga małżonków, jak i w płaszczyźnie wspólnoty małżeńskiej. Ujawnia się wówczas konieczność wspólnego przekraczania kolejnych etapów autokreacji do tej formy rodzicielstwa. Biografia małżeńska wyklucza sytuację, w której małżonkowie przechodzą tę drogę niezależnie od siebie, niejako obok siebie, niejako poza ich wspólnotą małżeńską. Jej konstruktywne znaczenie ujawnia się w dzieleniu się małżonków własnymi przeżyciami związanymi z trudnościami w samoprzekraczaniu mentalnej bariery między rodzicielstwem biologicznym a adopcyjnym. Kluczowymi elementami biografii małżeńskiej są wzajemne wspieranie się w:

a) radzeniu sobie z trudnym doświadczeniem niepowodzenia prokreacyjnego,

b) wzbudzaniu pragnienia bycia rodzicami adopcyjnymi i współtworzenia rodziny adopcyjnej,

c) dążeniu do bezwarunkowej akceptacji osoby dziecka poprzedzonej bezwarunkową akceptacją siebie jako rodziców adopcyjnych, 
d) afirmatywnym kształtowaniu stosunku do adoptowanego dziecka jako własnego dziecka.

Z uwagi na to, że autokreacja do rodzicielstwa obejmuje również wszystkie fazy bycia i stawania się rodzicem na etapie parentalnym, z czasem zyskuje na znaczeniu przenikanie się i interferowanie biografii małżeńskiej $\mathrm{z}$ biografią rodzinną. Wiąże się to $\mathrm{z}$ uczeniem się dialogu rodzinnego prowadzonego przez rodziców adopcyjnych i dziecko/dzieci adoptowane. Przestrzeń dialogu rodzinnego jest wówczas szansą na autentyczne otwarcie się na siebie przebiegające $\mathrm{w}$ duchu osobowego spotkania. Wówczas biografia rodzinna jest dziełem i zarazem dobrem wszystkich domowników. Jest ich wspólną historią życia rodzinnego.

Jedną z ważnych funkcji biografii rodzinnej w przypadku rodziny adopcyjnej jest szansa zrealizowania wartości pedagogicznej utożsamianej z jawnością aktu adopcji. Koresponduje ona ze wspólnotowym charakterem doświadczenia niezamierzonej bezdzietności małżonków, ich autokreacyjnego otwierania się na rodzicielstwo adopcyjne oraz stawania się rodzicami adopcyjnymi pozbawionego rodziny dziecka (lub rodzeństwa). Doświadczenia niezamierzonej bezdzietności oraz rodzicielstwa adopcyjnego nie sposób łączyć tylko i wyłącznie z wydarzeniami kształtującymi indywidualne biografie każdego z małżonków. Podobnie jak współtworzenie rodziny adopcyjnej należy do doznań, przeżyć i wydarzeń, które z istoty swej odnoszą się do rodziców i ich dziecka/dzieci. Zachodzą one bowiem we wspólnotowym wymiarze rzeczywistości życia rodzinnego.

$\mathrm{Na}$ specyfikę tak rozumianej autokreacji małżonków do rodzicielstwa adopcyjnego składają się zatem na etapie preparentalnym odrębne historie życia małżonków i dziecka sprzed jego adopcji oraz na etapie parentalnym wspólna ich historia współkształtowana w przestrzeni rodziny adopcyjnej. Biografie związane $\mathrm{z}$ ich życiem w okresie poprzedzającym bycie rodziną są ważnym elementem budowania ich tożsamości jako rodziców adopcyjnych i dziecka adoptowanego, a także rodziny adopcyjnej jako wspólnoty. Elementem zbliżającym ich do siebie, kształtującym i umacniającym ich więź, a także stabilizującym życie rodzinne jest właśnie biografia rodzinna. Rodzice i dzieci wspólnie tworzą i rozwijają:

a) opowieść o nowym ich życiu w realiach wspólnoty,

b) uczą się bycia rodzicem adopcyjnym i dzieckiem adoptowanym,

c) doświadczają swojej obecności w nowej rzeczywistości rodzinnej,

d) pełniej rozumieją to, co odczytują jako prawdę o swoim życiu, ujawniające się w nim dobro oraz piękno wzajemnie sobie okazywanej miłości. 
Namysł nad złożonymi przesłankami autokreacji małżonków do rodzicielstwa adopcyjnego odsłania pewną subtelność w rozumieniu biografii rodzinnej. Wyraża się ona $\mathrm{w}$ tym, że współkształtowana biografia w przestrzeni wspólnoty małżeńskiej jest jakościowo odrębną biografią małżeńską, która po utworzeniu rodziny adopcyjnej z czasem wkomponowuje się w biografię rodzinną. Obejmuje ona wydarzenia, doznania i przeżycia związane z niezamierzoną bezdzietnością i osobową autokreacją małżonków do rodzicielstwa adopcyjnego na etapie preparentalnym i parentalnym. Z kolei biografia rodzinna obejmuje doświadczanie wzajemnej obecności małżonków jako rodziców i ich dziecka/dzieci, wspólnego bycia ze sobą, współkształtowania atmosfery domu rodzinnego. Biorąc to pod uwagę, biografia małżeńska może, lecz wydaje się, że nie musi, w każdym jej aspekcie korespondować z biografią rodzinną. To, co je łączy, wiąże się z refleksyjnym odniesieniem się do specyfiki doświadczania relacji rodzic-dziecko we wspólnocie rodzinnej kształtowanej i nieustannie rozwijanej w sytuacjach spotkania nienaiwnego.

Charakterystycznym rysem biografii rodzinnej jest nieustanne (re)konstruowanie narracji o biograficznie istotnych faktach z historii wspólnoty rodzinnej i preferowanym sposobie ich interpretacji. Narracja ta jest wspólnie uzgadniana, zapamiętywana, przekazywana i jednocześnie tworzona w relacjach wewnątrzpokoleniowych i międzypokoleniowych w przestrzeni wspólnoty rodzinnej. Jest osobliwym zbiorowym obrazem pamięci losów rodziny, panujących w niej stosunków rodzinnych, mentalnej bliskości jej członków z innymi żyjącymi i zmarłymi członkami rodziny, wreszcie siły i specyfiki identyfikowania się z historią wspólnoty rodzinnej.

Na podłożu biografii rodzinnych wywiedzionych przez małżonków z ich rodzin generacyjnych kształtowana jest biografia małżeńska jako nowa jakość w budowaniu wspólnoty małżeńskiej, z której może wyłonić się biografia rodzinna wspólnoty prokreacyjnej i adopcyjnej. Kreowana przez małżonków ich biografia wspólnotowa nie jest prostym powieleniem biografii rodzinnych wywiedzionych z ich rodzin generacyjnych. Jednakże nie jest też od nich całkowicie niezależna. Biografia małżeńska jest bowiem zanurzona $\mathrm{w}$ ich biografiach indywidualnych, ukształtowanych w dużej mierze przez doświadczenia wywiedzione $\mathrm{z}$ ich rodzin generacyjnych. Stanowi więc w jakiejś mierze ich kontynuację. 


\section{UWAGI KOŃCOWE}

Rodzicielstwo w praktyce życia codziennego nie zachodzi w próżni życia społecznego, lecz jest zanurzone w przestrzeni stosunków małżeńskich i rodzinnych, a także stosunków sąsiedzkich, towarzyskich i formalnych kształtowanych w obrębie szerzej rozumianego otoczenia społecznego. Należy jednak podkreślić, że odniesienie się do rodzicielstwa z perspektywy rodzica odsłania najbardziej prymarny aspekt osobowej relacji rodzica z dzieckiem. Obecność współmałżonka(i) ma w tym kontekście znaczenie dopełniające, konstruktywne lub destruktywne, dla osobowej autokreacji podmiotu do rodzicielstwa. W wariancie konstruktywnym obecność ta generalnie sprzyja autorefleksyjnemu odniesieniu się podmiotu do własnego rodzicielstwa rozpoznawanego w różnych jego wymiarach. Nie jest więc obojętna dla przebiegu jego osobowej autokreacji. Za każdym razem stanowi ona jednak przejaw współkreacji zachodzącej w płaszczyźnie wspólnoty małżeńskiej, jako procesu towarzyszącego autokreacji do rodzicielstwa - nie stanowi zaś jego komponentu esencjonalnego.

W tym znaczeniu bycie rodzicem jest nieustannym stawaniem się w dążeniu do coraz bardziej dojrzałego rodzicielstwa. Urzeczywistnia się ono w sytuacji istotnego egzystencjalnie spotkania rodzica z dzieckiem. Wyjątkowość i niepowtarzalność tej sytuacji wyraża się w tym, że nic się w niej nie wydarzy bez autentycznej woli rodzica otwarcia się na dziecko, uznania go za własne, obdarzenia go miłością i zaangażowania w aktywne towarzyszenie mu na każdym etapie jego życia. Chodzi więc o bycie $z$ dzieckiem i dla dziecka wypełniające tajemnicę osobowego spotkania, w którym nikt nie może rodzica wyręczyć, ani też zastąpić. Każdy akt spełniania się w rodzicielstwie jest emanacją wolności wolnej woli rodzica w najbardziej radykalnej i zarazem najczystszej postaci. Wyraża się ona w osobistym rozstrzygnięciu rodzica: „mogę chcieć - lub nie chcieć” przyjąć i kierować się wartością obecności dziecka we własnym życiu i zaangażowanego towarzyszenia mu na każdym etapie jego życia (por. Wojtyła, 2000, s. 167; Tischner, 2000, s. 486). Ta możliwość przyjęcia lub odrzucenia wartości bycia i stawania się w rodzicielstwie jest źródłem wyzwania egzystencjalnego człowieka dorosłego rozpoznawanego w horyzoncie agatologicznym (por. Tischner, 2012).

Rozważania podjęte w tym artykule odsłaniają kaskadowo kilka głównych aspektów mentalnego i duchowego realizowania się w rodzicielstwie, biologicznym i adopcyjnym. Punktem wyjścia do tych rozważań jest uchwycenie istoty rodzicielstwa jako procesu urzeczywistniania dynamicznej wartości 
towarzyszenia dziecku. Przyjęcie perspektywy rozumienia rodzicielstwa jako rzeczywistości in statu nascendi odsłania jej integralny i nierozłączny związek z autokreacją jako procesem intencjonalnego i twórczego poszukiwania własnej drogi życiowej bycia i stawania się rodzicem. Podłożem wspomnianego związku jest osobotwórczy charakter autokreacji rozpoznawanej jako proces całożyciowego rozwoju człowieka dorosłego.

Autokreacja do rodzicielstwa obejmuje, z jednej strony, samookreślenie się w kontekście rozumienia wartości rodzicielstwa oraz antycypowanej koncepcji samego siebie jako rodzica, a z drugiej - (samo)tworzenie siebie, ja podmiotowego, poprzez projektowanie indywidualnej strategii urzeczywistniania koncepcji samego siebie osadzonej w konkretnych realiach życia. Ujawnia się w tym kontekście wymiar biograficzny autokreacji. Jego znaczenie wiąże się z autorefleksyjnym odniesieniem się do wartości doświadczeń biograficznych, będących emanacją historii życia rodzica, a więc przeszłości utrwalonej w jego pamięci biograficznej, w której to przeszłości tkwi źródło jego przyszłości. Człowiek powodowany imperatywem osobowego rozwoju przejawia orientację prospektywną - ku temu co chce, aby się spełniło, w czym upatruje sens własnej egzystencji, która bazuje na kapitale wiedzy biograficznej, uczeniu się i pracy biograficznej. Nie sposób zatem pomyśleć o autokreacji usytuowanej poza biografią, ani też pomyśleć o biografii pozbawionej sensu osobowej autokreacji, a zwłaszcza autokreacji do rodzicielstwa.

Kolejnym przybliżeniem tej problematyki jest nakreślenie ponadpodmiotowego podłoża procesu osobowej autokreacji utożsamianego ze społecznym charakterem trwania osoby dorosłej w sieci relacji i zależności małżeńskich oraz rodzinnych. Wyrazem tego jest analiza specyfiki subtelnych form współwystępowania autokreacji ze współkreacją, a także biografii indywidualnej z biografią zbiorową, małżeńską i rodzinną. Wieńczy ona rozważania związane ze znaczeniem biografii małżeńskiej w aktualizowaniu i rozbudowywaniu samowiedzy i samorozumienia małżonków podejmujących wyzwanie bycia i stawania się rodzicem dziecka osadzonego w przestrzeni rodziny biologicznej lub adopcyjnej.

Oryginalnym zamysłem przyjętej w pracy problematyki jest więc rozpoznanie współwystępowania kategorii biografii zbiorowej, utożsamianej z biografią małżeńską (męża i żony) i rodzinną (ojca, matki, dzieci) z kategorią biografii indywidualnej każdego z małżonków rozpatrywanych w perspektywie autokreacji do rodzicielstwa. Zważywszy na analityczny charakter artykułu kluczowe jest uchwycenie nieoczywistych relacji między biografiami 
zbiorowymi, kształtowanymi i utrwalanymi we wspólnotach małżeńskiej i rodzinnej, a biografiami indywidualnymi każdego członka wspólnoty rodzinnej.

\section{BIBLIOGRAFIA}

Alheit, P. (1994). The „Biographical Question” as a Challenge to Adult Education. International Review of Education, 40(3), 283-298.

Alheit, P. (1995). Biographical Learning. Theoretical Outline, Challenges and Contradictions of a New Approach in Adult Education. W: P. Alheit, A. Bron, E. Brugger, P. Dominice (red.), The Biographical Approach in European Adult Education (s. 57-74). Wiedeń: ESREA/ Verband Wiener Volksbildung.

BAKIERA, L. (2013). Zaangażowane rodzicielstwo a autokreacyjny aspekt rozwoju dorostych. Warszawa: Difin.

BARTNIK, Cz. (2008). Personalizm. Lublin: Wydawnictwo KUL.

BenNETT, J. (2015). Narrating family histories: Negotiating identity and belonging through tropes of nostalgia and authenticity. Current Sociology, 66(3), 449-465.

Bron, A. (2009). Biograficzność w badaniach andragogicznych. Dyskursy Młodych Andragogów, $10,37-54$.

Chudy, W. (2009). Pedagogika godności. Elementy etyki pedagogicznej. Lublin: Towarzystwo Naukowe KUL.

CYRAŃSKA, E. (2005). Duchowa rzeczywistość czyniąca człowieka osobą. W: F. ADAMSKI (red.), Wychowanie personalistyczne. Wybór tekstów (s. 59-68). Kraków: Wydawnictwo WAM.

Czerniawska, O. (1996). Trendy rozwojowe w zachowaniu ludzi dorosłych. W: T. WujeK (red.), Wprowadzenie do andragogiki (s. 36-46). Radom: Wydawnictwo Instytutu Technologii Eksploatacji.

CzerniawsKa, O. (1999). Wymiar czasu a przeżywanie starości. Ethos, 12, 3(47), 76-83.

DuBAs, E. (2005). Andragogiczne poszukiwania rozumienia dorosłości. W: E. DuBAs (red.), Człowiek dorosty istota /nie/ znana? (s. 41-57). Łódź-Płock: Wydawnictwo Naukowe NOVUM.

Dubas, E. (2009). Auksologia andragogiczna. Dorosłość w przestrzeni rozwoju i edukacji. Rocznik Andragogiczny, 133-149.

Dubas, E. (2015), Przygotowanie do dorosłości - być i stawać się dorosłym. Edukacja Dorostych, 1(72), 9-21.

DuBAS, E. (2017). O podmiotowości w kontekście pedagogicznym. Edukacja Dorosłych, 2(77), 21-36.

FolkiersKa, A. (2005). Jaka filozofia, jaka pedagogika? W: P. Dehnel, P. GuTOWSKi (red.), Filozofia a pedagogika. Studia i szkice (s. 42-55). Wrocław: Wydawnictwo Naukowe Dolnośląskiej Szkoły Wyższej Edukacji Towarzystwa Wiedzy Powszechnej.

FrankL, V.E. (1998). Homo patiens. Logoterapia i jej kliniczne zastosowanie. Pluralizm nauk a jedność człowieka. Człowiek wolny. Warszawa: Instytut Wydawniczy PAX.

Glanc, Z. (2011). Obraz dorosłości w dobie ponowoczesnej. Mozaika wymiarów dorosłości. Edukacja Dorostych, 1(64), 115-132.

GóRNIOK-NAGLIK, A. (2014). Edukacja kulturalna w liceum stymulatorem autokreacji młodzieży. Toruń: Wydawnictwo Adam Marszałek. 
GuARDinI, R.G. (1993). Struktura bytu osobowego. W: F. ADAMSKI (red.), Człowiek - Wychowanie - Kultura. Wybór tekstów (s. 25-38). Kraków: Wydawnictwo WAM.

Horowski, J. (2015). Wychowanie moralne wedtug pedagogiki neotomistycznej. Toruń: Wydawnictwo Naukowe UMK.

JARVIS, P. (2012). Transformatywny Potencjał uczenia się w sytuacjach kryzysowych. Teraźniejszość - Człowiek - Edukacja, 3(59), 127-134.

KANiowsKa, K. (2003). Antropologia i problem pamięci. Polska Sztuka Ludowa - Konteksty, 57(34), 57-65.

KaszTelan, M. (2012). Fenomen pamięci zbiorowej. In Gremium. Studia nad historia, kultura i polityka, 6, 185-198.

KAŹMIERSKA, K. (2012). Biography and memory. The generational Experience of the Shoah Survivors. Boston: Academic Studies Press.

Kiereś, B. (2016). Personalizm w pedagogice. Polska Myśl Pedagogiczna, 2, 271-281.

KierkegaARD, S. (2008). Czyny mitości. Kilka rozważań chrześcijańskich w postaci mów Kierkegaarda. Seria pierwsza. Kęty: Wydawnictwo Marek Derewiecki.

Kornas-Biela, D. (2000). Rodzina w opinii młodego pokolenia Polaków. W: D. KoRnAs-BielA (red.), Rodzina: źródlo życia i szkoła miłości (s. 109-134). Lublin: Towarzystwo Naukowe KUL.

Kornas-Biela, D. (2001). Współczesny kryzys ojcostwa. W: D. Kornas-BIEla (red.), Oblicza ojcostwa (s. 171-192). Lublin: Towarzystwo Naukowe KUL.

Kornas-Biela, D. (2009). Pedagogika prenatalna: nowy obszar nauk o wychowaniu. Lublin: Wydawnictwo KUL.

KostKiewicz, J. (2013). Kierunki i koncepcje pedagogiki katolickiej w Polsce 1918-1939. Kraków: Oficyna Wydawnicza „Impuls”.

KrĄPIEC, M.A. (2005). Człowiek jako osoba. Lublin: Polskie Towarzystwo Tomasza z Akwinu.

KunOwski, S. (1997). Podstawy współczesnej pedagogiki. Warszawa: Wydawnictwo Salezjańskie.

KURYŚ-SZYNCEL, K. (2010). Tematyczne narracje autobiograficzne kobiet i mężczyzn wobec tworzenia biografii rodzinnej. W: M. Straś-RomanowsKa, B. BARTOSZ, M. ŻURKo (red.), Psychologia wielkich i małych narracji (s. 131-151). Warszawa: Eneteia.

ŁADYŻYŃSKI, A. (2009). Małżeństwo? Nie, dziękuję! Rzecz o przyczynach niezawierania związków. W: A. ŁADYŻYŃSKI (red.), Rodzina we wspótczesności (s. 259-269). Wrocław: Wrocławskie Wydawnictwo Oświatowe ATUT.

ŁADYŻYŃSKI, A. (2014). Subsystem rodzicielski i jego znaczenie dla wspólnoty rodzinnej. W: J. BRĄGIEL, B. GÓRNICKA (red.), Rodzicielstwo w sytuacji dezorganizacji rodziny i możliwości wspomagania rodziców (s. 27-34). Opole: Wydawnictwo UO.

LalaK, D. (2010). Życie jako biografia. Podejście biograficzne w perspektywie pedagogicznej. Warszawa: Wydawnictwa Akademickie „Żak”.

MALEWSKI, M. (1990). Andragogika w perspektywie metodologicznej. Wrocław: Wydawnictwo UWr.

NowaK, M. (2001). Podstawy pedagogiki otwartej. Ujęcie dynamiczne w inspiracji chrześcijańskiej. Lublin: Redakcja Wydawnictw KUL.

Olbrycht, K. (2000). Prawda, dobro i piękno w wychowaniu czlowieka jako osoby. Katowice: Wydawnictwo UŚ.

OpOzDA, D. (2012). Rodzicielstwo a poczucie sensu życia. W: J. BrąGIEL, B. GóRnICKA (red.), Rodzicielstwo w kontekście współczesnych przemian społecznych (s. 71-89). Opole: Wydawnictwo UO. 
Ostasz, L. (1995). Autokreacja. Współkreacja. Spotkanie. W: J. PAWLICA (red.), Autokreacja czlowieka - między wolnościa a zniewoleniem. Materiaty VI Jagiellońskiego Sympozjum Etycznego (s. 19-23). Kraków: Drukarnia UJ.

OstrouCh-KAmiŃSKA, J. (2017). Konstruowanie „małżeńskiego ja”. Rodzina jako przestrzeń wsparcia i uczenia się partnerstwa małżonków. Rocznik Andragogiczny, 24, 61-74.

PopIELSKI, K. (1996), Koncepcja człowieka i jej znaczenie dla psychoterapii i poradnictwa - propozycje K. Wojtyły i V.E. Frankla. W: K. POPIELSKI (red.), Logoteoria i nooteoria. Logoterapia i nooterapia (s. 395-405). Lublin: Redakcja Wydawnictw KUL.

Rosenthal, G. (2000). Social transformation in the context of familial experience: biographical consequences of a denied past in the Soviet Union. W: R. BRECKNER, D. KALEKIN-FISHMAN, I. MiETHE (red.), Biographies and the division of Europe: experience, action, and change on the „Eastern Side” (s. 115-137). Opladen: Leske u. Budrich.

Rosenthal, G. (2002). Veiling and denying the past The dialogue in families of Holocaust survivors and families of Nazi perpetrators. The History of the Family, 7, 225-238.

Rowid, H. (1946). Podstawy i zasady wychowania. Warszawa: Instytut Wydawniczy „Nasza Księgarnia".

RytKönen, M. (2004). About the Self and the Time. Acta Universitatis Tamperensis 1046. Tampere: Juvenes Print.

SkARgA, B. (1995). Tożsamość Ja i pamięć. Znak, 480(5), 4-19.

SKIBIŃSKA, E. (2006). Mikroświaty kobiet. Relacje autobiograficzne. Warszawa: Wydawnictwo Instytutu Technologii Eksploatacji.

ŚLIWERSKI, B. (2011). Współczesny spór o istotę i zakres wychowania personalistycznego w Polsce. Annales. Etyka w życiu gospodarczym, 14(2), 11-25.

StARnAwSKI, W. (2012). Źródła i pedagogiczne konsekwencje redukcjonizmu antropologicznego. Paedagogia Christiana, 1(29), 11-29.

Strauss, A. (1993). Continual Permutations of Action. New York: Aldine.

ŚwiĄTKIEwICZ, W. (2016). Młodzież wobec małżeństwa i rodziny. Konteksty kulturowe i religijne. Zeszyty Naukowe Katolickiego Uniwersytetu Lubelskiego, 59, 4(236), 133-147.

Świtalski, W. (2015). Przygotowanie do dorosłości jako wciąż aktualny problem andragogiki. Edukacja Dorostych, 1(72), 117-125.

Tischner, J. (2000). Myślenie wedtug wartości. Kraków: Wydawnictwo Znak.

Tischner, J. (2012). Filozofia dramatu. Kraków: Wydawnictwo Znak.

UrbańSKi, R. (1986). Problem dorosłości i podmiotowości w andragogice. Oświata Dorostych, 7 , 392-395.

WĄSIŃSKI, A. (2018). Autokreacja małżonków bezdzietnych do wielowymiarowego rodzicielstwa adopcyjnego. Perspektywa pedagogiczno-antropologiczna. Łódź: Wydawnictwo UŁ.

WĄSIŃSKi, A., GóRnioK-NAGLIK, A., (2018), Multidimensional character of self-creation - theoretical and methodological overview. W: Ł. TOMCZYK, A. RYK, J. Prokop (red.), New trends and research challenges in pedagogy and andragogy (s. 109-124). Kraków: Uniwersytet Pedagogiczny w Krakowie.

WojtyŁa, K. (2000). Osoba i czyn oraz inne studia antropologiczne. Człowiek i Moralność IV. Lublin: Towarzystwo Naukowe KUL.

WojtyŁA, K. (2003). Rozważania o istocie człowieka. Kraków: Wydawnictwo WAM. 


\section{BIOGRAFIE MAŁŻEŃSKIE I RODZINNE ROZPATRYWANE W PERSPEKTYWIE AUTOKREACJI DO RODZICIELSTWA}

\section{STRESZCZENIE}

W artykule podjęto namysł nad specyfiką współwystępowania i wzajemnych powiązań między kilkoma odrębnymi znaczeniowo kategoriami: rodzicielstwem, autokreacją i biografią. Przy czym rozważania te przebiegają w kilku płaszczyznach zorientowanych na uchwycenie istoty: a) rodzicielstwa rozpoznawanego jako procesu urzeczywistniania dynamicznej wartości towarzyszenia dziecku, b) autokreacji ujmowanej w całożyciowym planie rozwoju osobowego człowieka dorosłego w kontekście jego dążenia do bycia i stawania się rodzicem, c) integralnego charakteru związku biografii indywidualnej i zbiorowej (wspólnotowej) z autokreacją osoby dorosłej przebiegającą w przestrzeni wspólnoty małżeńskiej i rodzinnej, d) biograficznego wymiaru autokreacji do rodzicielstwa biologicznego i adopcyjnego.

Celem artykułu jest przedstawienie argumentacji uzasadniającej tezę, że wspomniane kategorie nie tylko współwystępują, ale w praktyce współistnieją w określonych relacjach zależnościowych. Praca biograficzna małżonków i pozostałych członków rodziny rozpatrywana na poziomie indywidualnym zachowuje łączność symboliczną z biografiami małżeńską i rodzinną. Autokreacja małżonków zachodzi na podłożu ich autorefleksyjnego odniesienia się do własnej biografii zorientowanego prospektywnie. Rodzicielstwo wreszcie rozpatrywane jako proces osiągania dojrzałości rodzica w wieloaspektowo ujmowanym towarzyszeniu dziecku może się urzeczywistniać na podłożu jego osobowej autokreacji do rodzicielstwa.

Słowa kluczowe: autokreacja; rodzicielstwo jako proces; biografia małżeńska i rodzinna; pamięć biograficzna; rozwój osobowy.

\section{MARITAL AND FAMILY BIOGRAPHIES CONSIDERED IN THE PERSPECTIVE OF SELF-CREATION TO PARENTHOOD}

\section{SUMMARY}

The article discusses the specificity of coexistence and mutual relations between several meaningful categories: parenthood, self-creation and biography. These reflections take place in several planes oriented at capturing the essence: a) parenthood recognized as a process of realization of the dynamic value of accompanying a child, b) self-creation included in the lifelong plan of personal development of an adult in the context of his aspiration to be and become a parent, c) the integral nature of the relationship between individual and collective (community) biography and adult self-creation taking place in the space of married and family community, d) the biographical dimension of self-creation to biological and adoptive parenthood.

The aim of the article is to present the arguments justifying the thesis that these categories not only coexist, but in practice coexist in specific relationships. The biographical work of spouses and other family members considered on an individual level maintains a symbolic link with marital and family biographies. The self-creation of spouses takes place on the basis of their self-reflexive reference to their own biography oriented prospectively. Finally, parenthood, considered as the process of reaching maturity as a parent in the multi-faceted companionship of a child, can be realized on the basis of their personal self-creation to parenthood.

Key words: self-creation; parenthood as a process; marital and family biography; biographical memory; personal development. 